\title{
CHOLERA, QUARANTINE AND THE ENGLISH PREVENTIVE SYSTEM, 1850-1895
}

\author{
by
}

\author{
ANNE HARDY *
}

Cholera is popularly remembered as the disease which made the nineteenth century its own, appearing from obscurity to devastate Europe repeatedly in the years between 1830 and the 1920s. Six pandemics spread fear and alarm, terrible illness and horrible death, across the Continent before $1900,{ }^{1}$ distorting the true demographic significance of the disease and deflecting both contemporary and historical attention from the indigenous "diseases of society". ${ }^{2}$ Epidemic cholera had its origins in India; for Europe it was only an invader, as plague had been originally. In its status as invader, and in the magnitude of its geographical range, lay its impact and its influence on nineteenth-century society.

More than thirty years ago, Asa Briggs drew attention to the international significance of cholera, and stressed the need for comparative examination of responses to cholera in different countries and in different epidemics. ${ }^{3}$ Although the disease has since attracted much historical attention, this has been largely concentrated on individual epidemics (notably that of 1830-32), and on contemporary debates about the causes of the disease. ${ }^{4}$ It is only recently that studies which recognize and stimulate consideration of the wider European cholera experience of the period 1830-1900 have begun to appear, and the later history of the disease in Europe remains largely unexplored. ${ }^{5}$ Both the pattern of local responses to the later outbreaks, and the processes involved in cholera's gradual withdrawal from the Continent, merit investigation, as does the wider context of the development of

* Anne Hardy, MA, D.Phil., Wellcome Institute for the History of Medicine, 183 Euston Road, London NW1 2BE.

' Different authorities, with differing perspectives, give varying dates for the cholera pandemics. From the global perspective, dates are given as $1817-23$; 1826-37; 1846-62; 1864-75; 1883-94; 1899-1923: William Topley and Graham Wilson, Principles of bacteriology, virology and immunity, vol. 3, 7th edition, ed. G. R. Smith, London, Edward Arnold, 1984, p. 446. From the European perspective, the pandemic dates commonly accepted and adopted here are those given by Richard Evans, 1830-2, 1847-9, 1853-4, 1865-6, 1873, 1884, $1892-3$. Contemporaries sometimes took a different view, giving the dates as $1830-7 ; 1847-56 ; 1865-73 ; 1884 ; 1892$ : Philippe Hauser, Le choléra en Europe, Paris, Société d'éditions scientifiques, 1897.

${ }^{2}$ Margaret Pelling, Cholera, fever and English medicine 1825-1865, Oxford University Press, 1978, pp. 3-4.

${ }^{3}$ Asa Briggs, 'Cholera and society in the nineteenth century', Past and Present, 1961, 19: 76-96.

${ }^{4}$ Among a large literature see, Michael Durey, The return of the plague: British society and the cholera, 1831-32, Dublin, Gill and Macmillan, 1979; R. J. Morris, Cholera 1832. The social response to an epidemic, London, Croom Helm, 1976; Pelling op. cit., note 2 above; W. Luckin, 'The final catastrophe-cholera in London, 1866', Med. Hist., 1977, 21: 32-42; François Delaporte, Disease and civilisation: the cholera in Paris 1832, Cambridge, MIT Press, 1986; Roderick E. McGrew, Russia and the cholera, 1823-1832, Madison and Milwaukee, University of Winsconsin Press, 1965; Richard J. Evans, Death in Hamburg: society and politics in the cholera years, Oxford University Press, 1987.

5 See e.g., Richard J. Evans, 'Epidemics and revolutions: cholera in nineteenth-century Europe', Past and Present, 1988, 120: 123-46; F. M. Snowden, 'Cholera in Barletta 1910', Past and Present, 1991, 132: 67-103. 


\section{Cholera, quarantine and the English preventive system}

public health programmes in the different European countries. Although this paper focuses on the English experience of cholera after 1850, and on the development by the English health authorities of a system for excluding the disease from the country, this local history has a more than local significance. ${ }^{6}$ As a public health problem, cholera was recognized to be of international dimensions by 1850 , and, in the search for a coherent international preventive policy in the decades after 1850, the cholera experience of England was to prove crucial.

The last English cholera epidemic occurred in 1866, after which England was singularly successful in excluding the disease. The traditional European response to invading infections was quarantine: cholera and the English example between them ended that tradition. Quarantines were a marked feature of government responses to the first and second pandemics; yet they transparently failed to prevent outbreaks of cholera, and were often abandoned. ${ }^{7}$ It was this failure that stimulated the first attempts to achieve an international policy for limiting the disease. The first International Sanitary Conference was convened at Paris in $\mathbf{1 8 5 1}$ to examine Europe's position in respect of cholera, and to try to establish an international consensus on enforcing broadly uniform precautionary measures. ${ }^{8}$ It was the first of a series of such conferences, most of which foundered on the issue of trade, quarantine and international shipping. The majority of European countries continued to favour quarantine as the means of preventing the entry of sea-borne cholera, but Britain was adamantly opposed to any restriction on the freedom of trade. While medical men and diplomats struggled to reach agreement at repeated international conferences-at Constantinople in 1865, Vienna in 1874, Rome in 1885-the English preventive authorities evolved and perfected a system of sanitary surveillance coupled with detailed preventive measures (isolation and disinfection), which appeared to meet the challenge of imported cholera effectively. The British success in avoiding epidemic cholera after 1870, together with increasing familiarity with the causes and movements of the disease, were influential in changing attitudes among European observers. At the Conference of Venice (1892) and Dresden (1893), the value of the English system was finally acknowledged, and its techniques adopted as the basis of international preventive action. ${ }^{9}$

Britain's position as an island nation extensively involved in international trade was a crucial determinant in the development of her cholera exclusion policy. Politically and economically committed to freedom of trade, the country had to devise measures other than quarantine for the exclusion of imported infectious disease. ${ }^{10}$ The absence of epidemic cholera from the country in the decades after 1870 has often been attributed to sanitary

\footnotetext{
${ }^{6}$ This account of preventive approach to cholera as an invader complements and extends my discussion of the preventive authorities' contribution to controlling the indigenous infectious diseases: Anne Hardy, The epidemic streets: infectious disease and the rise of preventive medicine, 1856-1900, Oxford University Press, in press.

${ }^{7}$ Evans, op. cit., note 4 above, p. 245.

${ }^{8}$ A brief account of the International Sanitary Conferences is given in Hauser, op. cit., note 1 above, ch. 12. For a more extended treatment see Norman Howard-Jones, The scientific background of the international sanitary conferences, 1851-1938, Geneva, World Health Organisation, 1975. For the problems posed by India and the Indian trade see Mark Harrison, 'Quarantine, pilgrimage, and colonial trade: India 1866-1900', Indian Econ. Soc. Hist. Rev., 1992, 29: 117-44.

${ }^{9}$ Hauser, op. cit., note 1 above, pp. 534-8.

${ }^{10}$ For British quarantine see Charles F. Mullett, 'A century of English quarantine, 1709-1825', Bull. Hist. Med., 1949, 23: 527-45; J. C. McDonald, 'The history of quarantine in Britain during the 19th century', Bull. Hist. Med., 1951, 25: 22-44.
} 


\section{Anne Hardy}

improvement; ${ }^{11}$ indeed, Michael Durey has convincingly argued that the "ideal" conditions for the spread of cholera within the community had begun to disappear soon after the outbreak of $1847-48 .^{12}$ While there is no doubt that improving sanitary conditions and water supplies made a large contribution to England's freedom from cholera, the number of imported cases after 1870, and the persistence of waterborne typhoid in various parts of the country into the 1890 s, indicate that possibilities for the epidemic extension of cholera continued to exist. Closer examination of the circumstances of the European cholera visitations after 1866, and of the development of English sanitary legislation, suggests that good fortune and an alert public health organization played a significant part in Britain's virtual freedom from cholera.

\section{CHOLERA OBSERVED}

The mid-Victorian public health organization was empirical in its methods, and observation of the broad epidemiological behaviour of cholera, as revealed by its patterns of dissemination across Europe, was central to the development of England's defences against the disease. Already by the 1850 s, the European manifestations of cholera were being studied with interest by English sanitarians trying to predict the likely assaults of the disease on their own country. The pandemics of 1830,1846 and 1853 suggested that it moved outward from its homeland by successive steps, following overland trade routes and lines of communication. ${ }^{13}$ It would only reach England in the second year of a European visitation, although minor outbreaks generally occurred in the autumn of the first year, heralding a major epidemic in the following summer. The principal danger for England lay in the arrival of the disease at the Baltic ports, especially Hamburg: in 1832, 1848, and 1854, the epidemic outbreak of cholera at Hamburg was rapidly followed by the appearance of the disease in seaports on the east coast of England. ${ }^{14}$

Season was also important in timing the arrival of epidemic cholera; August and September were the months of most danger in England. ${ }^{15}$ The cholera vibrio is notoriously sensitive to heat and humidity. It can survive for days or even weeks in moist linen, but only for a few hours when exposed in hot dry conditions. It can also live in water for variable lengths of time depending on the $\mathrm{pH}$ factor, salinity and degree of contamination with other conditions. In nineteenth-century Europe, the long-term pattern, and local and seasonal distribution of the disease were partly determined by climatic variation, ${ }^{16}$ and this seasonal factor was in some degree recognized by contemporaries. By the mid-1850s, public health observers, tracing the movement of the disease across Europe, were able to view its approach with a certain dispassion. Until it reached the Baltic, there was little to fear; if it reached Hamburg in the late autumn, as it often did, there would be no major English outbreak until the following summer, when conditions for its resurgence and onward march were once again favourable.

\footnotetext{
"' For example, Anthony Wohl, Endangered lives: public health in Victorian Britain, London, Edward Arnold, 1983, p. 124. F. B. Smith, The people's health 1830 to 1910, London, Croom Helm, 1979, p. 233, draws attention to the part played by "strict national quarantine".

12 Durey, op. cit., note 4 above, p. 204.

${ }^{13}$ Hauser, op. cit., note 1 above, p. 533.

it Lancet, 1857 , ii: 374.

15 Ibid., 1894, ii: 444.

${ }^{16}$ Topley and Wilson, op. cit., note 1 above, pp. 449, 451 .
} 


\section{Cholera, quarantine and the English preventive system}

Growing familiarity with the behaviour of cholera bred little immediate complacency, however. More than any other decade, the $1850 \mathrm{~s}$ were haunted by the disease. The epidemic of 1853-4, following so close upon the heels of that of 1848-9, awoke fears that the disease might become indigenous, or at least that the intervals between epidemics would shorten still further. ${ }^{17}$ The presence of cholera in the Crimea, at a time when newspaper correspondents were revealing the horrors of the Crimean War to the British people, helped to keep it in the public eye. When the disease arrived at the Baltic ports and Hamburg in October 1857, the General Board of Health issued detailed preventive advice; a small outbreak at West Ham was widely regarded as a warning to expect a major epidemic in $1858 .^{18}$ The Lancet fulminated against the state of the Serpentine, and urged preventive action: "There are six clear months before us for sanitary improvements-six months for organising a thoroughly efficient staff of officers, and for pre-arranging a concerted method of action". ${ }^{19}$

Yet there is little evidence from the reports of London's newly appointed medical officers of health of any specifically cholera-induced sense of urgency in their work, while the reports of the new Medical Department of the Privy Council focus on smallpox and diphtheria in these years. Perhaps it was as well that the expected epidemic did not materialize in 1858. Possibly because of the great heat and drought of that summer-it was the year of the Great Stink in London-cholera retreated from the southern Baltic seaboard, to ravage instead Stockholm and St Petersburg. ${ }^{20}$ In 1859, however, it returned to Hamburg, and an English epidemic was confidently expected: cholera, remarked the Lancet, "now seems to become a periodical scourge to this country". ${ }^{21}$ A number of cases were introduced into London and Tyneside from Hamburg, ${ }^{22}$ but, again perhaps because of adverse weather conditions, there was no extension of the disease.

Throughout this anxious decade, the prevailing preventive attitude towards cholera was determined by pragmatism. ${ }^{23}$ Nothing certain was known of the immediate or circumstantial cause of the disease; the waterborne theory of cholera transmission received wide publicity, but little wholehearted acceptance. Debate about the true cause of cholera continued, with some espousing miasma theory, some water theory, and many a middle position, which took account of both. The reactions of the medical community to the threat of epidemic cholera in the autumn of 1857 reflected this diversity of opinion. ${ }^{24}$ There were, however, signs of a new confidence in dealing with cholera among the medical community. This was based not on any improved understanding of the etiology of the disease, but rather on past experience and on improved sanitary organization. Despite

${ }^{17}$ Lancet, 1858, i: 72.

${ }^{18}$ Ibid., 1857, ii: $374-5,369,478$.

${ }^{19}$ Ibid., 367, 369, 478.

20 Ibid., 1858, ii: 41, 363, 660. For the Great Stink see Carleton B. Chapman, 'The year of the Great Stink', Pharos, July 1972, pp. 90-103.

${ }^{21}$ Ibid., 1859, ii: 137.

22 Ibid., 137-8, 169, 226.

${ }^{23}$ Pelling, op. cit., note 2 above, p. 310, argues that the "main product of mid-nineteenth-century epidemiology was a kind of compromise . . an intelligent position consistent with interest, experience and methodology." I endorse this view. See also Christopher Hamlin, 'Predisposing causes and public health in early nineteenthcentury medical thought', Soc. Hist. Med., 1992, 5: 43-70.

24 Lancet, 1857 , ii: 374 . 


\section{Anne Hardy}

the little evidence of cholera-specific sanitary activity, the Lancet, for example, exhibited considerable faith in the efficacy of London's newly appointed medical officers of health:

At last a vigorous and vigilant administration has been organised in the Boards and Officers of Health, called into action by the Metropolis Local Management Act, for protecting the population of London against future assaults [of cholera]. That our defensive provisions in the capital are immeasurably superior to those of any former period cannot be doubted. ${ }^{25}$

This judgment was undoubtedly based on the prescription of general sanitary improvement: urging the importance of preparation for the expected major outbreak of the disease in 1858 , the journal's emphasis was firmly on sanitary improvement, efficient staff and a pre-determined course of action. ${ }^{26}$ Local activity, local improvement, were still seen as the key to successful prevention.

\section{THE LESSONS OF 1866}

By contrast with the 1850 s, the explosion of pandemic cholera in the 1860 s was met by an established sanitary organization, with nearly ten years of work behind it. In those years, considerable improvements had been effected in both the environment and public health organization of London and other large cities: in 1864, the Registrar-General thought the great towns in a far better condition than ever before to encounter cholera. ${ }^{27}$ Against this background, the English sanitary authorities viewed the movement of cholera across the continents of Asia and Europe from the 1860s with increased confidence; a confidence founded on the basis of accumulated evidence, and experience, of cholera as an associate of insanitary conditions.

Cholera, however, retained the ability to surprise. In 1865 , for the first time, it chose to approach Europe not by the recognized land route, but by sea. The disease broke out in Egypt in June 1865, and this, together with an unusual prevalence of diarrhoea in London, aroused considerable alarm in England. ${ }^{28}$ By mid-July the "epidemic tension" was high, and quarantine measures were being debated. ${ }^{29}$ While the government resolutely stated its opposition to quarantine, the alertness of the Medical Department and the GeneralRegister Office to foreign epidemics produced a positive response to the threat of cholera in 1866. John Simon traced the movement of the disease across the European continent throughout $1865 .{ }^{30}$ Reporting the outbreak of cholera at Rotterdam on 21 April 1866, the

\footnotetext{
${ }^{25}$ Lancet, 1857, ii: 367.

${ }^{26}$ Ibid., 369, 396.

${ }^{27}$ Annual report of the Registrar-General (henceforth $R G A R$ ), Parliamentary Papers (henceforth PP) 1867 xvii, p. 49.

${ }^{28}$ Briggs, op. cit., note 3 above, p. 87, states that cholera entered Britain from Egypt in 1866 . This is not strictly true, although the case is also made by Ernest Hart, 'Cholera and our protection against it', Nineteenth Century, 1892, 188: 638. There is no suggestion in John Netten Radcliffe's report that the two cases which might have infected the river Lea originated in Egypt; the first case was employed in a local brush manufactory, and it is possible that imported raw materials were contaminated. Radcliffe's findings clearly indicate that cholera was coming into Britain from many of the major Channel and Baltic ports (Rotterdam, Antwerp and Hamburg, for example) throughout May, June and July, and Radcliffe himself evidently considered the European connection to be the important one: Medical Officer's annual report to the Privy Council later to the Local Government Board, (henceforth MOARPCLGB) 1867 xxxII, Appendix 7f, pp. 265-7.

${ }^{29}$ Lancet, 1865 , ii: $99-100$.

${ }^{30}$ MOAR to PC, PP 1867 xxxvii, Appendix 7, pp. 264-5.
} 


\section{Cholera, quarantine and the English preventive system}

Lancet gave thanks for the "enlightened measures" of the Medical Department of the Privy Council, through which, "we may anticipate greater success in warding off this terrible enemy ... owing to the extension of sanitary improvements". ${ }^{31}$ In the event, the 1866 epidemic proved the cholera defences of the nation, and of London in particular, to be deficient in two vital respects: the cleanliness of water supply and the regulation of shipping. ${ }^{32}$ The medical authorities' experience of the 1866 cholera epidemic was important in several respects. It established the formula for dealing with local cholera outbreaks; a formula which was to be reissued at every cholera scare until the end of the century. It confirmed to many the significance of the quantity and quality of water supply, and resulted in the eventual extension of constant supplies throughout London. Imported simultaneously with the cattle plague which devastated British herds in the summer of 1866 , cholera pointed to the role of the country's ports in admitting communicable disease into the country. And finally, the 1866 epidemic increased the confidence of the medical community in their own ability, through sanitary improvement and rigorous sanitary supervision, to limit outbreaks of the disease where it was not transmitted through water. It was, however, the attention paid to quality of water supplies and the regulation of shipping in the years after 1866 that led to the country's virtual freedom from cholera in the last three decades of the century.

Doubts and difficulties continued, however, to surround issues of water purity before the twentieth century. ${ }^{33}$ This meant that the first element in the country's defences against cholera was her shoreline, the point of entry for the disease. Uncertain of the exact relationship between water and the transmission of cholera, and also of the exact efficiency of existing methods of water purification, English resistance to cholera after 1870 concentrated on safeguarding against the importation of cases. In this respect, the experience of 1866 was critical: it resulted in the refocusing of the English preventive effort. Cholera was no longer viewed as a local problem, but as one which must be met by a broadly based preventive scheme which took account of its status as invader, and of its means of international transmission.

\section{PORT SANITARY AUTHORITIES}

The cardinal importance of preventing the entry of dangerous communicable diseases into the country was recognized by the creation of a whole new division to the country's preventive organization, the Port Sanitary Authorities. For commercial and political reasons, the introduction of quarantine for shipping was out of the question. ${ }^{34}$ The experience of 1866 , however, convinced the medical community that some form of control on the entry of vessels from areas known to be affected by communicable diseases was an

${ }^{31}$ Lancet, 1866, i: 464.

${ }^{32}$ For the history of the 1866 outbreak in London see Luckin, 'The final catastrophe', op. cit., note 4 above, pp. 32-42; idem, Pollution and control: a social history of the Thames, Bristol, Adam Hilger, 1986, chapter 7.

${ }^{33}$ For progress and problems with water supplies see Durey, op. cit., note 4 above, p. 204; Anne Hardy, 'Water and the search for public health in London in the eighteenth and nineteenth centuries', Med. Hist., 1984, 28: 250-82, p. 273; idem, 'Parish pump to private pipes: London's water supply in the nineteenth century', Living and dying in London, Med. Hist., Supplement no. 11, London, WIHM, 1991, pp. 76-93; Christopher Hamlin, $A$ science of impurity: water analysis in nineteenth-century Britain, Bristol, Adam Hilger, 1990; A. C. Houston, Studies in water supply, London, Macmillan, 1913, chapter 7.

${ }^{34}$ See Mullett, op. cit., note 10 above, pp. 527-45; McDonald, op. cit., note 10 above, pp. 22-44. 
essential preventive measure. Already in 1858, the Epidemiological Society had been unanimous that medical inspection should be introduced for steamers and other vessels trading between Britain and other countries, particularly during the prevalence of epidemics. ${ }^{35}$ The importations of 1866 served to re-emphasize the lesson: as John Simon observed emphatically, "contagions current on the Continent of Europe must be deemed virtually current in England". ${ }^{36}$ Some attempt was made in the Sanitary Act 1866 to provide for the "shipping difficulty", 37 but when cholera became epidemic in Eastern Europe in 1871, and there were serious fears of its importation, the Medical Department took action. The authorities of the 48 leading ports were prepared for preventive action by the Department's inspectors with such success that a system of local port defence was given statutory confirmation in the following year. ${ }^{38}$

The establishment of the Port Sanitary Authorities in 1872 finalized the structure of the British preventive organization. The system offered both protection against the import of communicable disease and the regulation of sanitary conditions within ports. In the Port of London, the sanitary regulation of shipping was finally put on a regular footing, having been virtually absent in the past. Some accommodation for sick seamen had long been provided by the Seamen's Hospital Society, ${ }^{39}$ and during the cholera epidemic of 1866 this organization proved invaluable, not only in providing hospital facilities for seamen and coastal traders, but also in undertaking a ship-to-ship visitation. ${ }^{40}$ The sanitary conditions revealed by this inspection were not encouraging. The problem lay not so much in the ocean and coastal traffic of the port as in its regular residents. As the Lancet phrased it, no class was so totally unprotected by "even the ghost of a sanitary regulation".41 Between London Bridge and Blackwall hundreds of barges lay moored in tiers three or four deep, without either sanitary facilities or water supplies. The barges themselves provided only a couple of tiny cabins, in which whole families dwelt, and were ill-ventilated, poorly lit and insanitary; nearly all the cholera cases dealt with on the Belleisle hospital ship in 1866 came from this quarter. ${ }^{42}$

A leading part in the campaign for the greater regulation of shipping was played by Henry Letheby, Medical Officer of Health for the City of London. Letheby had for some time been concerned about sanitary conditions in the Port, ${ }^{43}$ and the shipping provisions of the 1866 Sanitary Act stimulated him to arrange the appointment of a special officer to inspect shipping within the City's jurisdiction, on the north side of the Thames between the Temple and the Tower. The City was the only London authority to take such a

35 Lancet, 1858, i: 72.

${ }^{36}$ MOARPC, PP $1866 \times x \times$ xiii, p. 43.

${ }^{37}$ Sanitary Act 1866, 29 \& 30 Vict. c. 90, secs. 29, 30. Nuisance authorities, with Privy Council permission, were allowed to regulate for the removal to hospital and maintenance there for as long as necessary any persons suffering from dangerous or infectious disorders brought into their districts by any ship or boat.

${ }^{38}$ Royston Lambert, Sir John Simon, 1816-1904, and English social administration, Bristol, McGibbon and Kee, 1963, pp. 435-6; Public Health Act 1872, 75 \& 76 Vict. c. 79, sec. 20. See also Lancet, 1871, ii: $227,326$.

${ }^{39}$ The Seamen's Hospital Society was responsible for the Dreadnought Hospital, Greenwich, established in 1763. The Hospital was taken over by the NHS in 1948, and was closed in 1988. In 1866 the Society borrowed the Belleisle from the Government as a floating hospital ship for cholera cases.

${ }^{40}$ Lancet, 1866, i: 527; ibid., 1871, ii: 326.

41 Ibid., 1866, ii: 130.

42 Ibid.

${ }^{43}$ Lancet, 1871, ii: 326. See also Letheby's annual reports, and his 'Report on the Sanitary Inspection of Shipping', 1868. 
measure, although the medical officers of both the Dreadnought Hospital and the Customs were by now convinced of the need for action-uniform action-along the whole course of the river, especially in respect of the sanitary condition of shipping and the import of infectious disease. ${ }^{44}$ The section of the Port supervised by the City's inspector represented only a tiny fraction of the total problem, and when cholera threatened in 1871, the Privy Council Medical Department organized a supervisory authority which represented jointly the various sanitary authorities which abutted on the Thames. ${ }^{45}$ In practice, the arrangement did not prove fully satisfactory, as most of the authorities were reluctant to finance the necessary measures. ${ }^{46}$ It was perhaps for this reason that under the Public Health Act, 1872, the City was constituted the sole sanitary authority of the Port of London, with all expenses of the port sanitary authority to be paid for from corporate funds. ${ }^{47}$

The first Medical Officer for the Port of London was Harry Leach, whose first appointment had been as assistant physician at the Dreadnought Hospital, and who had had charge of the Belleisle and organized the sanitary inspection of shipping during the cholera crisis of 1866. A young man of tact and good temper, boundless energy and undaunted courage in the face of difficulties, Leach took up his duties in July $1873 .{ }^{48}$ The task which he faced was formidable. London was then "the wealthiest, most populous, and worst arranged port in the world". 49 The Port of London sanitary district extended from Teddington Lock to the North Foreland, was 88 miles long, and included 8 sets of docks and 13 creeks. It was surrounded by 46 waterside authorities, each of which had had riparian powers in the Port before 1872 , but which now had no sanitary powers below the Trinity High Water mark within the limits of the Port. Six other bodies were more particularly concerned in the general business of the Port: the Customs; the Marine Department of the Board of Trade; Trinity House; the Thames Conservancy; the Thames contingent of the Metropolitan Police; and the dock companies. It was estimated that 25,000 vessels entered and left the Port yearly, while there were 2,300 sailing and 4,000 "dumb" barges on the Thames, the latter alone containing a population of about $15,000 .{ }^{50}$ Compared with the sanitary supervision of even a populous London parish, the sanitary management of the Port of London was no light task.

Although sanitary conditions within the ports were a subject of daily concern, the greatest vigilance of the English port sanitary authorities was directed towards the import of communicable and infectious disease. Disease prevention policy in the first ten years of the port authorities' existence was to a large extent exploratory and experimental, but the powers which the port authorities exercised in cases of communicable disease were

\footnotetext{
${ }^{44}$ Henry Letheby, 'Report on the sanitary condition of shipping', 1868, pp. 6, 9.

${ }^{45}$ Lancet, 1871, ii: 326, 343, 413, 448.

${ }^{46}$ For Letheby's complaints see MOAR, City of London, 1870-1, p. 50; Lancet, 1871, ii: 645.

47 Public Health Act, 1872, sec. 20.

${ }^{48}$ Leach died in harness, of tuberculosis in November 1879. He was succeeded by another strong and genial personality, William Collingridge, who served the City Corporation for twenty years as Port Medical Officer, and a further twelve as $\mathrm{MOH}$ for the City.

${ }^{49}$ Lancet, 1871 , ii: 270.

${ }^{50}$ Half yearly report of the Medical Officer (henceforth MOHYR), Port of London, December 1873, p. 4; Lancet, 1871, ii: $270,326$.
} 


\section{Anne Hardy}

already greater in several respects than those of their mainland colleagues. Under the Quarantine Act, 1825, all infectious disease on board vessels entering port, with the important exception of coasters, was to be reported to the Customs, who detained such vessels until their release was recommended by the officer of the local sanitary authority. ${ }^{51}$ The Public Health Act, 1875, made possible the compulsory removal to hospital of every patient suffering from an infectious disease on shipboard, and enabled the port sanitary authorities, with the approval of the Local Government Board, to make regulations for the compulsory notification and isolation of infectious cases. With respect to disinfection, ships and vessels in harbour were subject to the jurisdiction of the sanitary authority, in the way that houses were in mainland sanitary districts.

Within a decade or so, however, it became apparent that ships' captains and crews were evading the regulations, because they resented the interference with their business and their liberty which sanitary regulation represented: a more precise definition of the port authorities' powers was clearly required. In 1885, therefore, the Public Health (Shipping) Act explicitly extended the powers granted to mainland local authorities in 1875 in respect of infectious disease to the port authorities. These provisions enabled port MOHs to cleanse and disinfect where they considered it necessary to check the spread of infectious disease; to destroy infected bedding, etc.; and to remove those without proper lodging or accommodation who were suffering from dangerous infectious disease to hospital. Port sanitary authorities could make regulations for the removal to hospital of infected persons brought in by ships; and might impose a penalty for the exposure of infected persons and articles, and for the letting of lodgings in houses where infectious disease existed. They were empowered to provide hospitals; to recover the cost of hospital maintenance from patients; and to provide a gratuitous temporary supply of medicine and medical attendance for poor persons in their districts. ${ }^{52}$

The sphere of the port sanitary authorities' interest extended widely beyond their own port limits, and contributed significantly to the overall success of the system. Apart from such indications of foreign epidemics as were obtainable from the Registrar-General's reports, ${ }^{53}$ careful attention was paid to the disease condition of ports of contact both at home and abroad. While something may be gleaned of the extent of such monitoring from various sources, Henry Armstrong, the very able Medical Officer of Health for Tyneside, left a description of the activities of his department which probably reflects the practices current in the great ports in the latter decades of the century. On Tyneside, extensive use was made of the available printed sources of information. The medical and daily press, the Shipping Gazette, and other journals were examined daily for reports of disease abroad. A list of vessels bound for the Tyne from infected ports was kept, in which were entered the name of the ship, the date of her passing different ports on her voyage, and the expected date of her arrival. Ships on this register were visited without delay by sanitary officers on arrival. The sanitary officers routinely interrogated the captains of all vessels boarded for

\footnotetext{
5I Quarantine Act 1825 (6 George IV c. 78), secs. ix, xiv, xvi.

52 Public Health Act 1875 (38 \& 39 Vict. c. 55), secs. 110, 120-1, 124-6, 128, 130, 131-3. Public Health (Shipping) Act 1885 (48 \& 49 Vict. c. 35 ).

${ }^{53}$ The General Register Office kept a wary eye on foreign epidemics and regularly published statistics relating to international disease incidence.
} 


\section{Cholera, quarantine and the English preventive system}

information of infectious disease in their port of origin. ${ }^{54}$ It was this type of informationseeking, systematic monitoring and determined sifting of individual reports that constituted the country's most effective barrier against the import and dissemination of dangerous infectious diseases in the years after 1885 .

Early experience proved the need for such diligence. In his first six months as port MOH, Harry Leach discovered "pretty exactly" the quarters from which cholera might be expected. Leach quickly became aware that London was being made a port of call for large emigrant ships carrying parties of between 100 and 300 persons, which were hauled into dock and remained two or three nights in the port. These vessels and their freight often came from continental ports infected, or suspected of infection, with cholera. In July, for example, the steamship Iris carrying Danish and Swedish emigrants brought two unsuspected cholera cases to London. ${ }^{55}$ Once the emigrants were settled in their emigrant lodging houses in Whitechapel (lodging houses with this especial function were to be found in Whitechapel, the City and St George-in-the-East) a serious outbreak occurred (28 cases among 82 persons, with 8 deaths), and measures had to be taken to prevent the spread of the disease in the East End. ${ }^{56}$ Throughout 1873, cholera was more or less prevalent in many parts of Europe, notably in Paris, Le Havre, Rotterdam and Antwerp, and during the autumn isolated cases were introduced into London, Liverpool and Southampton from Hamburg, Rotterdam, Caen and Le Havre. In most cases the disease did not appear until the vessel had reached, or nearly reached, port. Leach's reaction was to request all ship's brokers to furnish him with early notice of the arrival of emigrant ships. In every case the MOH boarded such ships between Southend and Gravesend, and systematically examined both passengers and crew, thus, he observed, not complicating commercial interests by detaining the ship. ${ }^{57}$

Even in 1873, Leach was plainly worried by the public health consequences of trade and technological progress. The opening of the Suez Canal and the extension of the world railway system yearly increased European contact with the East, where cholera was endemic. In Leach's view, cholera was fast becoming endemic on the European continent, and London's "almost hourly communication" with the Baltic and Mediterranean ports placed it in considerable danger. ${ }^{58}$ The Medical Department of the Local Government Board was equally worried: George Buchanan, Simon's successor, saw the behaviour of cholera in Europe in the years 1865-74 as "of very evil omen", and instructed Netten Radcliffe, the Department's cholera expert, to examine the behaviour of the disease in Europe in these years. ${ }^{59}$ Leach had, however, already taken practical action. In 1874 , he made a European tour, visiting Le Havre, Antwerp and Rotterdam, as likely to provide fair

\footnotetext{
${ }^{54}$ H. E. Armstrong, Port sanitary administration on the Tyne, 1888, p. 1. Armstrong's description of his procedure in suspicious cases is quoted verbatim in Anne Hardy, 'Smallpox in London: factors in the decline of the disease in the nineteenth century', Med. Hist., 1983, 27: 111-38, p. 129.

55 MOHYR, Port of London, December 1873, pp. 11-12. See also PP 1874 xxxi, p. 6, fn.

${ }^{56}$ MOARLGB, PP $1874 \mathrm{xxxi}$, p. 5. See also MOARLGB, PP $1875 \mathrm{xl}$, Appendix 1: 'The diffusion of cholera and its prevalence in Europe', by J. Netten Radcliffe.

${ }^{57}$ MOHYR, Port of London, December 1873, p. 12.

58 Ibid., p. 21.

${ }^{59}$ MOARLGB, PP 1875 xl, pp. 145, 153-368. British attitudes to foreigners-“wogs begin at Calais"-perhaps reinforced this preventive suspicion of Europe as the source of cholera. For such attitudes see Colin Holmes, John Bull's island: immigration and British society 187I-1971, London, Macmillan Education, 1988, pp. 56-84, 294-302.
} 


\section{Anne Hardy}

examples of the disease procedures of France, Holland and Belgium. His findings were revealing. In the French ports, the "utmost secrecy and mystery" prevailed concerning the existence of cholera, so that it was almost impossible to obtain an exact date, or to form correct conclusions. In the Belgian ports early news of epidemic cholera was not difficult to obtain, because all medical men were compelled to inform the secretaries of the sanitary commissions of any occurrence of the disease. It was not considered advisable, however, to publish exact bills of mortality until the epidemic had ceased. In Holland, everything was apparently open. All physicians were under heavy penalty to inform the burgomasters of every case of cholera. The latter advertised the facts in the daily journals, informed the sanitary commissions, and quarantined affected houses by directing that a distinguishing card be placed in the windows. ${ }^{60}$ Not surprisingly, Leach concluded that news of cholera cases in Belgium and Holland was probably sufficiently reliable for preventive purposes; while shipping from France should always be treated with caution.

In spite of the efforts of very capable MOHs such as Leach and Armstrong in the major ports, the procedures for the detection of imported disease on incoming ships continued unsatisfactory until the Shipping Act, 1885. In 1882, following representations from the United States that smallpox had been imported by immigrant shipping, the Medical Department ordered an inquiry into the sanitary aspects of emigration and immigration, appointing F. E. Blaxall, a former naval man, to the task. ${ }^{61}$ Blaxall's report indicated an increasing solicitude among the organizers of emigration for the health and comfort of the emigrants, and concluded that the quantity of preventable sickness spreading among such people was relatively small. His report on the English port arrangements for detecting infectious disease among arrivals from abroad was not so satisfactory. He pointed to a lack of any organized relation between the shipping companies and the sanitary authorities, and was particularly anxious for the regular medical inspection of foreigners landing in English ports. His suggestions for the improvement of sanitary practices in the ports and on shipboard, which chiefly concerned medical inspection of passengers and crews, were based on his own experience of what was practicable in naval terms. ${ }^{62}$ Blaxall's inquiry certainly demonstrated the desirability of some form of medical control on what was now a very considerable emigrant traffic: between 1820 and 1881 , the number of emigrants passing through British ports had increased tenfold, from 123,528 in the quinquennium $1815-20$ to $1,347,827$ in $1876-81 .^{63}$

The cholera scare of 1883-4 compounded anxieties about port preventive organization. Cholera broke out in the Egyptian port of Damietta in June 1883, and although the epidemic was over by September, the thousands of British troops stationed in Egypt led to grave fears of its importation. ${ }^{64}$ Netten Radcliffe had retired from the Medical Department because of ill health in 1882, and George Buchanan was conscious that the Department's cholera expertise had been seriously diminished. The regular official monitoring of the progress and fluctuation of the disease in other countries had not been maintained, and

6) MOHYR, Port of London, June 1874, p. 62.

${ }^{61}$ MOARLGB, PP 1883 xxviii, p. 635, Appendix 14.

62 Ibid., p. 636. Blaxall had been medical officer aboard HMS Caledonia when the ship experienced an outbreak of cholera in June 1850 . This was dealt with by medical inspection, isolation and treatment. Apparently similar practices on other vessels suggest that this was a standard formula. Ibid., p. 789.

6.3 Ibid., p. 783.

${ }^{64}$ MOARLGB, PP 1884-5 xxxiii, p. 12. 


\section{Cholera, quarantine and the English preventive system}

Buchanan felt unable to assess the likelihood of epidemic cholera spreading through Europe from Egypt. ${ }^{65}$ Fresh prevention orders were issued to the port sanitary authorities, and a memorandum on cholera precautions distributed to other local authorities. The import of rags from Egypt was forbidden for the duration of the epidemic there, although it was not known whether cholera had ever been imported in rags. ${ }^{66}$ These measures were repeated in 1884, when epidemic cholera spread through France (causing between seven and eight thousand deaths), Italy and Spain, and were supplemented by a hasty inspection of the arrangements of 42 major port and riparian sanitary authorities. These were found to be on the whole satisfactory, ${ }^{67}$ but the legislation of the following year did much to regularize practices in the various different authorities, establishing a common ground of sanitary powers between port, riparian and mainland public health authorities.

Britain was fortunate in her cholera experiences in both 1872 and 1884. In the former year, John Simon recorded a handful of introductions: three at London, two at Liverpool, one at Southampton, and "at least one" at Swansea. Of these, the most serious was the Iris incident in London: Simon noted the danger to London as being "extremely great". ${ }^{68}$ In 1884 Buchanan had only three importations to report: a troopship arriving at Portsea; and a steamship from Marseilles and an Italian mail steamer at Cardiff. ${ }^{69}$ In London, Leach's successor William Collingridge "scrupulously maintained" emergency precautions in 1883 and 1884. All vessels arriving regularly direct from Marseilles received special attention; ${ }^{70}$ and arrangements were made for the medical inspection of every vessel entering the river, in the event of any serious spread of the disease making such a course advisable. ${ }^{71}$ There can be little doubt of the efficiency of Collingridge's arrangements: they were described as "excellent" by Shirley Murphy, the highly critical MOH of the LCC. $^{72}$

\section{FREEDOM FROM CHOLERA AFTER 1867: PREVENTION AND PUBLIC CONFIDENCE}

The failure of cholera to challenge English defences seriously in these years, as in $1857-9$, lay only partly in the English preventive system. It was probably important that no sustained epidemic wave of the disease reached Europe, and it was certainly significant that it did not reach the Baltic ports. The challenge of imported cholera during the $1880 \mathrm{~s}$, as shown by the importations into the Port of London, was never very great (Table 1).

The 1890s were, however, a very different matter. Between 1892 and 1897, 118 cases were brought into the Port of London, of which 58 were introduced in 1895 (Table 1). ${ }^{73}$ The final great European pandemic of cholera began in the spring of 1892. Two centres of infection were soon identified: Paris, where the disease broke out in April 1892, and

\footnotetext{
6.5 Ibid., pp. 12-13.

${ }^{66}$ Ibid., p. 12, Appendix A, nos. 14 b, 14 c. The memorandum on precautions against the spread of cholera, as Buchanan admitted (p. 205), was almost verbatim that issued by Simon in 1866 and 1871 .

${ }^{67}$ Ibid.

${ }^{68}$ MOARLGB, PP 1874 xxxi, pp. 6-7.

${ }^{69}$ MOARLGB, PP 1884-5 xxxiii, p. 204.

${ }^{70}$ These were the Peninsula and Oriental, Messageries Maritimes, and Trieste boats.

71 Lancet, 1884, ii: 119.

${ }^{72}$ MOAR, London County Council, 1892, p. 26.

${ }^{73}$ In this year cholera cases were introduced from Buenos Aires, St Petersburg, and Kronstadt: $M O H Y R$, Port of London, June 1895, pp. 12-13; ii, p. 12.
} 
Anne Hardy

Table 1: CHOLERA CASES IMPORTED INTO LONDON, 1884-1901

$\begin{array}{cccc}\text { Year } & \text { Cases } & \text { Year } & \text { Cases } \\ 1884 & - & 1893 & 15 \\ 1885 & - & 1894 & 10 \\ 1886 & - & 1895 & 58 \\ 1887 & 7 & 1896 & 4 \\ 1888 & 2 & 1897 & 12 \\ 1889 & - & 1898 & 1 \\ 1890 & - & 1899 & - \\ 1891 & - & 1900 & 1 \\ 1892 & 19 & 1901 & - \\ \text { (Source: Annual Reports } \text { of the Medical Officer for the Port of London.) }\end{array}$

Russia. From these two centres the disease spread swiftly out across Europe. ${ }^{74}$ The worst outbreak was at Hamburg, where between mid-August and mid-November 16,956 cases were recorded, with 8,605 deaths. ${ }^{75}$ Even before the Hamburg epidemic, the English authorities were on the alert. On 18 June, the Local Government Board medical officer, Richard Thorne Thorne, issued a memorandum in which he noted that on five of the seven occasions on which cholera had visited Britain, it had travelled by the Russian route-across Russia to the Baltic ports, and from there commonly extending to the North Sea and British Channel ports. It was from here that the disease had "several times" reached England, notably from Hamburg. ${ }^{76}$ In 1892 also, this linkage proved very clear: cholera broke out at Hamburg on 16 August; the first imported case was recorded in England on 25 August. ${ }^{77}$ Between 25 August and 18 October, 35 cases of cholera were imported, but none extended beyond arrivals at the ports involved. ${ }^{78}$

The warning of 1892 did not go unheeded. When the scale of the 1892 epidemic became clear, the Medical Department conducted a hasty survey of the condition of the port and riparian sanitary authorities. The unsatisfactory arrangements which were found in many ports, and the continued prevalence of the disease abroad, prompted a more extensive survey in 1893. Known in the Department as the "Cholera Survey", 79 this was published as the Port and Riparian Sanitary Survey, $1895 .^{80}$ Although when this survey was begun only one third of the 60 ports had a satisfactory and efficient sanitary administration, ${ }^{81}$ the arrangements for the medical inspection of vessels and persons-the crucial factor in cholera prevention-was found satisfactory in all but five. ${ }^{82}$ In certain districts, however,

\footnotetext{
${ }^{74}$ MOARLGB, PP 1894 xxxix, pp. xvii-xxii. Cholera had spread to Russia from British India, via Afghanistan, Persia and Turkestan in 1892-3.

${ }^{75}$ Ibid. The anatomy of this epidemic has been marvellously laid bare in all its aspects by Evans in Death, op. cit., note 3 above.

${ }^{76}$ MOARLGB, PP 1894 xl, Appendix A, no. 16.

${ }^{77}$ Ibid., p. 8.

78 Ibid.

${ }^{79}$ Ibid., p. 391.

${ }^{80}$ Port and riparian sanitary survey, PP 1895 lii.

${ }^{81}$ This was defined as including a competent and adequately remunerated $\mathrm{MOH}$; sanitary inspectors; an infectious disease hospital; disinfection facilities; adoption of the Infectious Diseases Notification Act 1889 and of section 125 of the Public Health Act 1875. In a third of other ports the administration was "lax and inefficient", the remainder falling in between. The lax ports were: Beaumaris, Boston, Chepstow (which had no foreign trade), Cowes, Dartmouth and Totnes, Falmouth and Truro, Harwich, Hayle, Ispwich, King's Lynn, Milford, Portsmouth, Preston, River Blyth, Sandwich, Scilly Isles, Wells and Yarmouth.

${ }^{82}$ Port and riparian sanitary survey, PP 1895 lii, pp. vi, viii.
} 
notably London, River Tyne, Hull and Goole, Southampton, Weymouth, Plymouth, Bristol, Cardiff, Bury-and-Cadoxton, Swansea and Liverpool, the medical inspection arrangements were not only highly satisfactory, but were carried out by the MOHs with such devotion to duty, that the Inspectors concluded they must have "largely contributed to the marked success with which imported cholera was controlled at nearly all English ports during 1892 and 1893". 83 In 1893, cholera appeared in 62 localities, of which 15 were metropolitan sanitary districts. There were 287 cases and 135 deaths; but in 42 districts only single cases were known. These included 14 of the metropolitan districts. In only one metropolitan district was there more than 3 cases, and in only five districts overall was there a loss of more than 10 persons. $^{84}$

Britain's freedom from epidemic cholera after 1866 had produced in many quarters the confident belief that such epidemics were a thing of the past. ${ }^{85}$ Although the Medical Department and local sanitary officers exercised extra vigilance and diligence in precautionary arrangements during each fresh European crisis, ${ }^{86}$ England's limited experience of cholera between 1867 and 1892 encouraged public complacency. During these years, generations grew up who had no personal experience of cholera epidemics, yet were aware of the disease as a constant threat abroad. As a result, the 1890s witnessed a marked discrepancy of emphasis between preventive action and public reaction to the threat of a cholera invasion.

The difference in public response to cholera between 1866 and 1892 reflects the growth of confidence in the sanitary service, as well as a wider public interest in sanitary matters. There was a far greater response in anticipation of cholera in 1892 than there had been in 1866. In 1866, cholera was no longer a novelty; its coming was beginning to be seen as a cyclical event; and in that year also the previous eruption of rinderpest - the cattle plague whose progress across Europe had been scrupulously followed by the Medical Department-absorbed public attention and distracted anxieties about cholera. ${ }^{87}$ At this time, too, the Medical Department was privileged in its sources of information and in its interest in European sanitary matters. Before the major outbreak of cholera in England in early July, the progress of the disease abroad had only been sparsely reported in the public press. ${ }^{88}$ English interest in cholera in 1866 was essentially insular in character. The intellectual effects of advancing technology are very evident in the contrasting cholera reportage of 1866 and 1892-3: the development of the telephone and the telegraph, the extension of railway networks in Europe, and the emergence of passenger steamship fleets, had revolutionized journalistic perspectives. By 1892, The Times, for example, carried lengthy and detailed reports from its special correspondents on cholera in Hamburg and Russia, while notices of the progress of the disease in distant parts of the world studded its pages. Readers of The Times would have been hard pressed to maintain an ignorance of European cholera and the threat to England in 1892.

83 Ibid.

${ }^{84}$ The districts concerned were Grimsby (127 deaths), Hull (17), Ashbourne, Derbyshire (15), Cleethorpes (11), and Clacton, Essex (11).

${ }^{85}$ Lancet, 1871, ii: 645; MOAR, Camberwell, 1883-4, 'Memorandum on cholera', p. 203.

${ }^{86}$ See MOARLGB, PP 1884-5 xxxiii, pp. 12-14; Appendix A, nos. 14(b), 14(c); MOAR, Camberwell, 1883-4, 'Memorandum on cholera', p. 203; MOAR, Strand, 1883-4, Appendix, pp. li-lxxii; ibid., 1884-5, pp. 15-20.

${ }^{87}$ Norman Longmate, King cholera. The biography of a disease, London, Hamish Hamilton, 1966, pp. 212-13.

${ }^{88}$ The Times, for example, carried only a bare handful of such references between April and July 1866. 


\section{Anne Hardy}

Journalistic interest in the prospect of cholera in 1892 seems to have generated a greater public awareness of that prospect than in 1866, among the educated classes at least. Nor can it be doubted that the activities of the preventive authorities contributed to this awareness: already in the summer of 1892, they were taking "infinite pains" to make their work efficient. ${ }^{89}$ Yet the zeal of the sanitary authorities in this respect may also have been counter-productive. Although there was no indication of any "epidemic tension" or panic over the threat of cholera, ${ }^{90}$ there were those who considered that this might be the result of the sanitary authorities' energetic reaction. On 5 September 1892, The Times carried a letter which sought to remind the general public that "the greatest ally of cholera is fear". The writer pointed to the differences in scale between epidemic cholera in the East-a death-rate of 559 per 10,000 at Damietta in 1883 - and in England: death-rates of 30, 11 and 7 per 200,000 in the "epidemics" of 1849, 1854 and 1866. He thought it not unreasonable to assume that if cholera reached England that year, mortality would be less than in 1866, and recommended going about one's own business, "in the ordinary way":

This I venture, with some experience to say is a safer course than being frightened into exceptional precautions, preventives, and remedies. ${ }^{91}$

Nonetheless, cholera provoked an extensive reaction in 1892. The Times leader of 5 September, while applauding the "foresight, zeal and activity" of the sanitary authorities, elaborated the argument by pointing out that sanitary offenders were a relatively small proportion of the community. In a passage remarkable for its unscientific logic, the paper urged the authorities to temper zeal with discretion, to take pains to do good, but only by stealth.

The class . . likely to grow nervous under the steady shower of warnings and exhortations now being poured out upon them is considerable, and the importance of the fact is manifest when it is remembered that fear ... is the most potent ally of epidemic cholera ... Provident fear in their [the authorities'] breasts may be the mother of safety, but should it spread to those under their charge it can only sap the spirit of the garrison and make things easy for the enemy. ${ }^{92}$

Behind these remonstrations may be detected a whole spectrum of social and economic fears; no longer that cholera itself should damage the established order and prosperity of the country, but that the anticipation of cholera should do so.

It was evidently a potent anxiety. By the following spring when the sanitarians were fully expecting a major outbreak of the disease, Arthur Shadwell, The Times correspondent in Germany and Russia the previous year, complained irritably of the attitude of the press, which was encouraging the widespread popular belief that cholera was always more or less present on the Continent, and that the outbreaks at Hamburg and

${ }^{89}$ The Times, 3 September 1892.

${ }^{90}$ Ernest Hart, 'Cholera and our protection against it', Nineteenth Century, 1892, 188: 650; Metropolitan Asylums Board annual report (henceforth MABAR), 1893, p. 264.

${ }^{91}$ The Times, 5 September 1892 . For the preventive riposte to this letter see Hart, op. cit., note 90 above.

92 The Times, 5 September 1892. The paper went on to note that "sensational statements" had been made, which received "a certain degree of support from the fussy action of local authorities here and there". 
Paris presented no greater danger than those successfully encountered on many previous occasions, "with the laudable but superfluous intention of allaying an alarm which does not exist". 93 Twenty-seven years of immunity from epidemic cholera had done their work: for most Englishmen, it seems, its continued existence on the Continent was a further illustration, if need be, of superior English standards of hygiene, and generally greater degree of civilization.

For informed sanitarians, however, the public optimism of 1892 was misplaced; with cholera at Hamburg, the danger to England must be considered grave. Arguments in favour of quarantine were again rehearsed. ${ }^{94}$ The Medical Department deployed Dr Barry to monitor the diffusion of cholera through Europe, and by the late summer of 1892 was issuing precautionary advice. ${ }^{95}$ New measures were taken to control the passage of emigrants from the Baltic, and a Cholera Order was issued on 6 September. ${ }^{96}$ Meanwhile, the Lancet, manifesting almost hysterical alarm, lauded the new controls on the passage of emigrant Russian Jews, and urged extensive attention to preventive measures. ${ }^{97}$ The Metropolitan Asylums Board hastily appointed Arthur Shadwell to supervise emergency arrangements in case of an epidemic in London, while the city's local authorities and medical officers rehearsed their cholera provisions and prepared stocks of posters. ${ }^{98}$ Similarly extensive precautionary arrangements had been made in $1884,{ }^{99}$ but Shadwell considered in retrospect that the country had never been exposed to such danger from cholera since $1866 .^{100}$

It is plain that neither in 1884 nor in 1892-3 were the preventive authorities taking any risks. In both these pandemics elaborate arrangements were made to deal with any outbreak of cholera in London, and the preparations in London in 1892, in particular, highlighted the similarities and contrasts in the approach of professionals and public to the prospects of a cholera epidemic. There was no panic, but whereas the public health authorities took the epidemic threat seriously, and prepared accordingly, public attention was not seriously engaged. Indeed, a whole chaotic, preventively anarchistic spectrum of popular preoccupations and beliefs was ranged against the professional cohesion of the preventive services. While the newspapers were anxiously peddling the calming view that the country was in no real danger of cholera, very real fears were evidently entertained by some sectors of the population. ${ }^{101}$ These were fuelled by the reported handful of cases,

9.3 MABAR, 1893, part vi, p. 264.

${ }^{94}$ See Thorne Thorne's explicit rejection of quarantine, MOARLGB, PP 1894 xxxiv, pp. xxiv-xxix. British practice at this date involved the examination of vessels on entry to the port, and removal to hospital of sick passengers and crew. Ships in port were then inspected daily for the duration of the incubation period of the disease as recognized at the time, i.e., for up to 15 days.

95 MOARLGB, PP 1894 xxxix c 7412, Part III, pp. xvii-xxx; Appendix 12: 'Report by Dr Barry on the origin and progress of the western diffusion of cholera during the year $1892^{\circ} ;$ MOARLGB, PP $1894 \times 1$, Appendices 14-20.

96 MOARLGB, PP 1894 xxxix, Appendix no. 16.

${ }^{97}$ Lancet, 1892, ii: 591.

${ }^{98}$ Newington Vestry minutes, 21 September 1892; MOAR, St Giles, 1892, pp. 74-9; MOAR, Mile End Old Town 1892, pp. 11-12; MOAR, Plumstead, 1892-3, p. 99; Camberwell Vestry annual report, 1892-3, p. 245; 1893-4, pp. 252-3.

${ }^{99}$ E.g. MOAR, St George-in-the-East 1884, p. 43.

${ }^{100}$ MABAR, 1893, part vi, p. 264. See also Lancet, 1893, ii: 1071.

101 See, for example, Newington Vestry annual report, 1893-4, p. 30. 


\section{Anne Hardy}

notably by the death of a cleaner at the House of Commons from undoubted Asiatic cholera in September 1893. ${ }^{102}$ On the other hand, Arthur Shadwell reported sourly on the lack of public co-operation encountered in his attempts to establish the metropolitan cholera service: "In this respect our enlightened British democracy has shown no more intelligence than the benighted peasantry of Russia". ${ }^{103}$

British shortsightedness and obstinacy manifested itself especially over the siting of the ambulance stations. In part, this was perhaps a reflection of the general attitude towards infectious disease hospitals ("not in my back yard"), but Shadwell, who took an educated interest in popular politics, hinted at deeper reasons. He eventually managed a fairly satisfactory provision of ambulance stations throughout the city, except in Rotherhithe. Here only two stations could be arranged, the Workhouse Infirmary and the Metropolitan Asylums Board's own South Wharf. Both Shadwell and the Medical Officer of Health, Josephus Shaw, made repeated attempts to obtain more, since they considered Rotherhithe a prime cholera target, and it was a district of many suitable yards and other places. The owners of these premises were, however, resolute in declining permission for their use,

on the ground that the presence of a cholera litter would be seized by the labour agitators ... as a pretext for causing trouble among the working men. ${ }^{104}$

It is a notable feature of the list of cholera stations that less than a dozen of the 133 appear to have been privately owned establishments, rather than local government, Poor Law, Police or hospital premises. ${ }^{105}$

Britain was in many respects fortunate to escape cholera in 1892-3. Vigilant and well-prepared sanitary authorities might nonetheless have been hard-pressed by any concerted assault of the disease. Symptomless carriers of cholera were a factor which no preventive action could hope to counter on any significant scale, while the dangers associated with the freedom of travel through the Channel passenger ports was well recognized. ${ }^{106}$ The outbreak at Grimsby and Cleethorpes in August 1893, in which 127 people died, and from where cases were traced to twenty-six towns in the Midlands and the North, from Gloucester and Hereford in the west to Newcastle-upon-Tyne, gave clear warning of the consequences of inefficient sanitary supervision and poor sanitary circumstances. $^{107}$ The serious prevalence of typhoid in the valley of the Tees meanwhile

\footnotetext{
${ }^{102}$ For this case see MOARLGB, PP 1894 xl c. 7539, Appendix no. 6, pp. 123-4: 'Report by Dr Deane Sweeting on a fatal case of cholera in Westminster'; ibid., Appendix 7, pp. 125-6: 'Memorandum as to advice given with regard to the disinfection of certain portions of the House of Commons' by Dr S. Monckton Copeman. According to Shadwell, attempts were made to hush up or garble the truth of this event: $M A B A R$, 1893, part vi, p. 267.

10.3 $M A B A R, 1893$, part vi, p. 264.

${ }^{104}$ Ibid., p. 261-2.

I0S Ibid., part vi, 'Report on the Board's cholera arrangements', Appendices A and B.

${ }^{106}$ Dr Yunge-Bateman, 'Cholera from a passenger port point of view', Public Health, 1892-3, 5: 261-2; Lancet, 1893, i: 424.

${ }^{107}$ For this outbreak see MOARLGB, PP 1894 xl, Appendix no. 2, pp. 47-88: 'Report on cholera in 1893 in Grimsby and Cleethorpes', by Dr Reece. Preventive anxieties were particularly sharp on this occasion because Grimsby fish were sold throughout the country, while Cleethorpes was already a thriving pleasure resort. The Grimsby cockle beds were known to lie beside the local sewer outfall: Lancet, 1893, ii: 636 .
} 


\section{Cholera, quarantine and the English preventive system}

illustrated that the diffusion of cholera by water was still a possibility. ${ }^{108}$ Once again, however, seasonal and geographical factors seem to have been significant in preventing disaster.

The most serious epidemic of cholera in Europe in 1892 was that at Hamburg; and from Hamburg, as experience showed, lay the greatest danger to England. Detailed examination of the circumstances of 1892 suggest the narrowness of England's escape. The Hamburg epidemic broke out on August 16, rushing to a climax in the last fortnight of August and the first week of September, and thereafter declining until it disappeared at the end of October. ${ }^{109}$ The timing of the epidemic outbreak at Hamburg was of critical significance in determining whether or not cholera would issue a major challenge to England across the North Sea; and in 1892, cholera arrived in Hamburg too late. By 25 August, when the first imported case from Hamburg was recorded, the year was already past the season at which cholera most readily found foothold in the country. ${ }^{110}$ The possibilities of a major epidemic escalation were small by the time the disease reached London in early September. Secondly, the European ports most seriously affected by cholera, such as Hamburg and Antwerp, were distant enough that infected persons could be expected to be showing typical symptoms of cholera on arrival, and early recognition of the disease by the port sanitary medical staff was much easier. ${ }^{11}$

Despite the alarm caused by Hamburg, the greatest possiblity of danger, as far as the English preventive authorities were concerned, was not in 1892, but in the following year, since cholera in the past had generally reached England in the second year of its European visitations. ${ }^{112}$ In 1893, however, the disease made no appearance in Hamburg before mid-September, ${ }^{13}$ although it was active during the spring and summer in the Low Countries, France and elsewhere in Germany. The first imported cases arrived on Tyneside from Nantes as early as 25 June; the infection at Grimsby, which had begun in early August, was traced to Antwerp. ${ }^{114}$ Once again, these ports were at a sufficient distance to facilitate the detection of cases, except, as the case of Grimsby proved, where the city and port sanitary authorities were inexcusably negligent. The outbreak at Grimsby, and its minor consequences, are evidence of the effectiveness of the wider sanitary organization, for there was no diffusion of the disease in the twenty-six towns to which the infection was carried from Grimsby and Cleethorpes. It may be, nonetheless, that England was once again protected from a more severe onslaught of cholera by the climatic factor. The summer of 1893 was one of those dry, hot summers that characterized the $1890 \mathrm{~s}$, and which was probably inimical to the prolonged survival and disseminative properties of cholera. As Arthur Shadwell pointed out, the wide geographical spread of cholera in Europe during 1893 was accompanied by a comparatively low mortality, and although increased knowledge and improved sanitary conditions might have had some part to play

\footnotetext{
${ }^{108}$ Lancet, 1893, ii: $1071,1144,1198$. For the Tees Valley problem see PP 1893-4 xlii c 7054, pp. 261-528, 'Supplement in continuation of the report of the Medical Officer for 1891'; 'Enteric fever in the Tees Valley', Lancet, 1893, ii: 1198.

${ }^{109}$ Evans, op. cit., note 4 above, p. 293, Fig. 9.

${ }^{110}$ MOARLGB, PP 1894 xl, p. vii; Lancet, 1893, ii: 445.

111 Ibid.

112 Public Health, 1892-3, 5: 12.

113 Evans, op. cit., note 4 above, p. 490.

114 Lancet, 1893, ii: 445; MABAR, 1893, part vi, pp. 266-7.
} 
in this, it was hard not to think that the exceptionally dry season had more to do with it. ${ }^{115}$ In England, for example, the greatest diffusion of the disease, and nearly all the cases, occurred north of a line from the Wash to the Severn, in that part of the country least affected by the drought. ${ }^{116}$

The incursions of 1893 represented the last extension of cholera into the English mainland. In 1894 the disease was severely epidemic in Russia, and Germany, Belgium, Holland, Hungary and Turkey were also affected. In France, however, cholera was on the retreat, and by 1895 it was waning in Russia, and had retreated still further from Western Europe, into Galicia, Turkey, Egypt and Morocco. It was not without its old pandemic powers, however, for when in February 1896 Russia was finally declared free of cholera, a severe visitation was beginning to make itself felt in Egypt. ${ }^{17}$ Past experience had by now so reinforced the confidence of the British public health authorities in their preventive system and in the modified danger which cholera in the Near East presented, that the Egyptian outbreak raised little concern. By 1898, cholera had disappeared from the list of the Medical Department's current anxieties, to be replaced by bubonic plague. ${ }^{118}$

If the larger movements of cholera were to some extent determined by the vagaries of season and climate, there is no doubt that sanitary circumstances and personal habits of cleanliness were major elements assisting its spread and influencing the locality of epidemic outbreaks. Recognition of these two sets of factors, within the constraint of a national maritime policy of freedom of trade, and in association with an internal preventive policy of detailed isolation for infectious disease, formed the basis of the English defence against cholera in the last three decades of the nineteenth century. Through the medium of the International Sanitary Conferences, and later of the International Conferences on Hygiene and Demography, the premises of English policy were given wide publicity on the European Continent, and came to be generally accepted with respect to the limitation of cholera dissemination by shipping in the last years of the century. ${ }^{119}$ Britain's sanitary surveillance of international shipping comprised the final plank in a national preventive system which was widely admired by contemporaries-it was, the Finn Alfred Palmberg noted, the most complete and precise in the civilized world - and Britain's success at excluding cholera after 1866, like her falling death-rates from tuberculosis, was regarded as proof of the superiority of that system. ${ }^{120}$

While circumstances and good fortune certainly played their part in preserving England from epidemic cholera in the last three decades of the century, the systematic development of her sanitary defences, and the policies of a forward-looking central medical department supported by a dedicated local preventive network, appear to have been critical in holding repeated cholera attacks at bay. The calm with which the general public faced the greatest

115 MABAR, 1893, part vi, p. 269.

116 Ibid.

117 MOARLGB, PP 1896 xxxvii, p. 316; MOARLGB, PP 1897 xxxvii, p. 21 ; MOARLGB, PP 1898 xl, p. 18.

118 MOARLGB, PP 1899 xxxviii, pp. 30-8; ibid., Appendix A, no. 18: Dr Bruce Low 'On the diffusion of bubonic plague', pp. 257-318.

119 Hauser, op. cit., note 1 above, p. 538.

120) Alfred Palmberg, A treatise on public health and its applications in different European countries, London, Swan Sonnenschein, 1893, p. 3, cited in Anne Hardy, 'Public health and the expert: the London medical officers of health 1860-1919', in R. M. MacLeod (ed.), Government and expertise: specialists, administrators and professionals, Cambridge University Press, 1988. See also the speech by Pierre Brouardel published in Public Health, 1899-1900, 13: pp. 797-8. 
of these apparent threats in 1892-3 was partly the result of improved domestic sanitary conditions, but was also based on confidence bred of past experience, on an improved understanding of the means by which the disease was transmitted and on broad popular ignorance of its epidemiological behaviour. It was those who remembered the epidemic of 1866 who were aware of the dangers of indifference, and who knew, as did Ernest Hart, that epidemic cholera was a disease which "struck down masses of the population in limited localities", that still feared its import in $1892 .{ }^{121}$ If the mystery of cholera had been exploded by the end of the nineteenth century, familiarity with its causes and conditions did not enable the preventive establishment to view its entry into the country with equanimity.

${ }^{121}$ Hart, op. cit., note 90 above, p. 651. 